\title{
Comprehensive Waste Management and the Importance of Landscape Heritage Preservation
}

\author{
Izarelly Rosillo Pantoja \\ Universidad Autónoma de Querétaro, Santiago de Querétaro, Mexico
}

\begin{abstract}
Sectioned view of the environment and its regulation under Mexican law has been exceeded for failure to enforce these rules, origin of the impact production processes, human depredation and his wasteful consumption that have been applying and developing exponentially. The model of conservation of the heritage landscape comprises an ambit non-sectored, but integral and sustainable of the environment, that it would allow transformations of large metropolis in polycentric metropolis region as well as the transformation of rural backwardness, in the development of polycentric micro regions, these strategies are the most suitable instrument for the sustainability remain focused in a system of strategic planning-in the medium and long term of landscaping organization. Within the integral management and prevention of waste generation, educational and cultural strengthening from the perspective of heritage landscape allows to open paths of communication between landscape and man, a consciousness state guideline to sustainable consumption and civil participation, are key aspects of change and have great relevance to conserve which today comprises the heritage landscape of our nation, and at the time will truly meet the legal provisions that our own constitution provides.
\end{abstract}

Keywords: landscape heritage, Mexico, waste

Earth has evolved in different forms and paces, causing steady changes in the environment. Men depend on Earth's biological diversity to satisfy their basic needs and ensure their survival. Human activities of production, consumption, and predation have altered the face of the earth. By destroying ecosystems, humans have affected the natural evolution of living organisms and limited biological diversity. Consequently, the extinction of species and sites has increased, and humans' quality of life has decreased. In Mexico, accelerated changes have occurred in ecological history, including the deterioration of the environment and the exhaustion of natural resources ${ }^{1}$. The main threats to our country are deforestation, soil degradation, and the

Corresponding author: Izarelly Rosillo Pantoja, Bachelor of Laws, MA in State and Municipal Public Administration, Ph.D. candidate in law, Universidad Autónoma de Querétaro, Mexico, exercised several functions in private companies as manager and legal director, and teaches at Universidad Autónoma de Querétaro, advisor in environmental law, litigation attorney and technical secretary at Querétaro's Network for Handling Waste (REQMAR, A.C.); research fields: constitutional, notarial law, and Amparo. E-mail: izarellyrosillo@msn.com.

${ }^{1}$ The Ministry of the Environment and Natural Resources (SEMARNAT) and the National Institute of Ecology have conducted studies concerning the loss of natural capital in Mexico. These data have been collected into the System of National Accounts, based on previous data by the System of Economic and Ecological Accounts (SCEEM). It is important to recognize the environmental deficit that exists in Mexico's productive and economic processes. Environmental policy should focus on preservation and conservation. However, efforts have been slow compared with the heightened damage of environmental impacts and loss of natural resources. SEMARNAT, "Programa estratégico sobre el capital natural”, consulted January 3, 2011 at http://elearning.semarnat.gob.mx/cte/MATERIALESAPOYO/DERECHO\%20AMBIENTAL/Contenidos/Documentos\%20oficial es/Programa\%20Estrat\%C3\%A9gico\%20sobre\%20el\%20Capital\%20Natural.doc. 
loss of vegetal ground cover.

The pollution of rivers and protected natural areas due to inadequate waste management has caused an environmental deficit of 3.7\% of the gross domestic product (GDP) for the years 1997-2002. The results for the years 2003-2007 appear in the following chart $^{2}$ (see Figure 1).

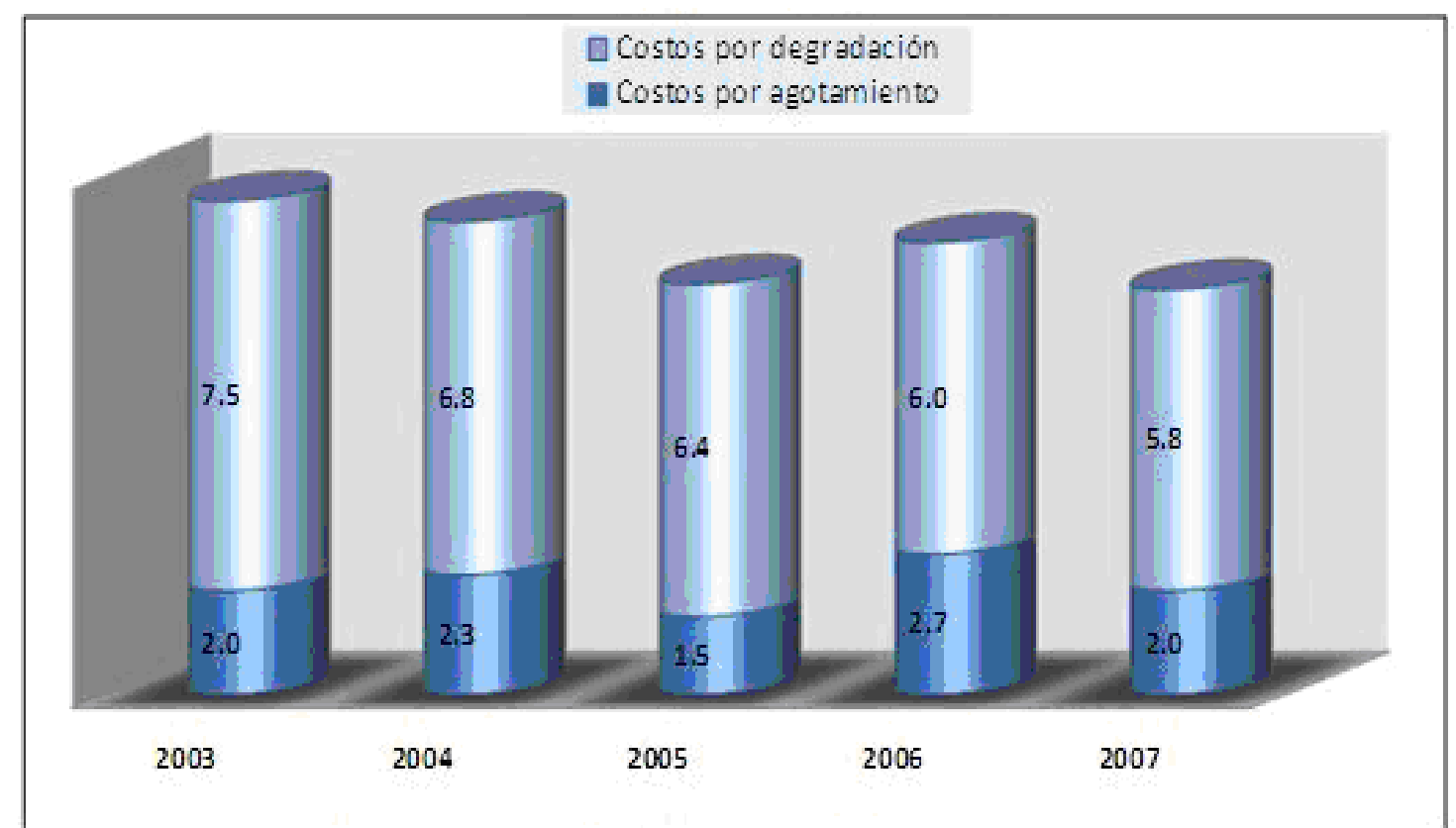

Figure 1. Total costs due to environmental exhaustion and degradation, as a percentage of the GDP (2003-2007). Source: Mexican System of Economic and Ecological Accounts (SCEEM, in Spanish) ${ }^{3}$.

Environmental impact for the years 2007-2012 was an average of 10.5\% of the GDP in current prices. In 2002, costs due to exhaustion and degradation of resources reached 623,075 million Mexican pesos-10\% of the GDP. However, expenses aimed at preventing or diminishing environmental damages was of only 33,099 million pesos- $5.3 \%$ of the costs of degradation. The data are supported by the Ministry of the Environment and Natural Resources (SEMARNAT, in Spanish), the office in charge of environmental policy. In the years after 2002, the budget for remediating degradation has increased in 200\%. However, population and environmental liabilities have also increased ${ }^{4}$. The preliminary study for 2012 shows that costs due to exhaustion and environmental degradation would amount to 985,064 million pesos, whereas only 143,066 million would be used for environmental protection ${ }^{5}$. Only in 2002, the deficit between environmental degradation and money used to remediate it amounted to 589,976 million pesos. In 2012, this deficit was of

\footnotetext{
${ }^{2}$ Consulted January 3, 2011 at http://elearning.semarnat.gob.mx/cte/MATERIALESAPOYO/DERECHO\%20AMBIENTAL/ Contenidos/Documentos\%20oficiales/Programa\%20Estrat\%C3\%A9gico\%20sobre\%20el\%20Capital\%20Natural.doc.

3 The National Institute for Statistics and Geography (INEGI) creates a yearly update for the System of Economic and Ecological Accounts in current values. This allows us to know how much Mexico's environmental deficit amounts to. Said study points out productive processes as the main cause of environmental damage. This means legislation appointing the environment as a protected legal entity has been insufficient. INEGI, "Comunicado especial", consulted at http://www.inegi.org.mx/ inegi/contenidos/ espanol/prensa/Boletines/Boletin/Comunicados/Especiales/2004/Junio/comunica3.doc.

${ }^{4}$ INEGI, System of National Accounts: Economic and Ecological Accounts of Mexico, 2006-2010, Mexico, INEGI, 2012, consulted July 20, 2015 at http://www.inegi.org.mx/prod_serv/contenidos/espanol/bvinegi/productos/derivada/economicas/ medio\%20ambiente/2006-2010/SCEEM0610PS.pdf.

${ }^{5}$ Consulted July 20, 2015 at http://www.inegi.org.mx/prod_serv/contenidos/espanol/bvinegi/productos/derivada/economicas/ medio\%20ambiente/2006-2010/SCEEM0610PS.pdf.
} 
841,998 million pesos. This reflects an alarming situation in matters of ecological economy for Mexico ${ }^{6}$ (see Figure 2).

\begin{tabular}{|c|c|c|c|c|c|c|c|c|}
\hline Año & PIB & $\begin{array}{c}\text { PIB } \\
\text { Ecológico } \\
\text { (PIBE) }\end{array}$ & $\begin{array}{c}\text { Costos totales } \\
\text { por } \\
\text { agotamionto y } \\
\text { degradacib́n } \\
\text { ambiental } \\
\text { (CTADA) }\end{array}$ & $\begin{array}{c}\text { Gastos on } \\
\text { prolecoción } \\
\text { ambiental } \\
\text { (GPA) }\end{array}$ & $\begin{array}{l}\text { PIBEI } \\
\text { PIB }\end{array}$ & $\begin{array}{c}\text { CTADN } \\
\text { PIB }\end{array}$ & GPACTADA & $\begin{array}{c}\text { GPA/PIB } \\
\text { a } \\
\text { precios } \\
\text { bdásicos' }^{1}\end{array}$ \\
\hline 2003 & $7,696,035$ & $7,043,365$ & 652,670 & 44,807 & 91.5 & 8.5 & 6.9 & 0.6 \\
\hline 2004 & $8,690,254$ & $7,996,018$ & 704,236 & 50177 & 91.9 & 8.1 & 7.1 & 0.6 \\
\hline 2005 & $9,424,602$ & $8,667,68 B$ & 756,934 & 57,009 & 92.0 & 8.0 & 7.5 & 0.6 \\
\hline 2006 & $10,520,793$ & $9,722,967$ & 797,826 & 64,796 & 92.4 & 7.6 & B.1 & 0.6 \\
\hline 2007 & $11,399,472$ & $10,544,785$ & 854,687 & 80,256 & 92.5 & 7.5 & 9.4 & 0.7 \\
\hline 2008 & $12,256,864$ & $11,338,259$ & 918,605 & 97,066 & 92.5 & 7.5 & 10.6 & 0.8 \\
\hline 2009 & $12,072,542$ & $11,235,677$ & 836,865 & 121,004 & 93.1 & 6.9 & 14.5 & 1.1 \\
\hline 2010 & $13,266,858$ & $12,380,590$ & $8 B 6,268$ & 126,176 & 93.3 & 6.7 & 14.2 & 1.0 \\
\hline 2011 & $14,508,784$ & $13,559,399$ & 949,385 & 140,636 & 93.5 & 6.5 & 14.8 & 1.0 \\
\hline 2012 & $15,561,472$ & $14,576,405$ & 985,064 & 143,066 & 93.7 & 6.3 & 14.5 & 1.0 \\
\hline
\end{tabular}

Figure 2. Total costs due to environmental exhaustion and degradation, 2003-2012. Source: National Institute for Statistics and Geography, System of Economic and Ecological Accounts (SCEEM).

The author's aim in this study is to increase knowledge and awareness on landscape heritage. This concept's importance must be recognized and incorporated into Mexican legislation. As the author will try to prove, landscape heritage is intrinsically related to the prevention and comprehensive management of waste.

\section{A Brief Historical Background: Nature Preservation in Article 27}

Mexican legislation had not recognized the importance of nature preservation until the Constitution of 1917. Venustiano Carranza's first project received harsh criticism, based on it not reflecting the actual problems of the country. Lawyer and sociologist Andrés Molina Enríquez ruled out the project as insufficient in his book Los grandes problemas nacionales. To Molina Enríquez, Carranza had not contemplated the realities and necessities of Mexican society. José I. Lugo, chief of the Labor Office at the Ministry of Promotion, joined Molina Enríquez's criticism. Together, they convinced the Constitutional Assembly to discuss the importance of nature preservation.

Pastor Rouaix, a member of the assembly, joined Molina Enríquez and Lugo and helped them make nature preservation a constitutional subject. As they said, "Nature has established a constant relationship between actions and their results, and when this relationship is broken life is made impossible" ${ }^{\text {.7 }}$. The 66th ordinary session

\footnotetext{
${ }^{6}$ Izarelly Rosillo Pantoja, “Ética y justicia ambiental en el Estado constitucional mexicano”, in Juan Ricardo Jiménez Gómez et al. (coords.), Ética y justicia. Reflexiones y planteamientos intemporales, México, Porrúa, 2015.

7 The project was presented in the 66th ordinary session. Eduardo Rabasa, La Constitución y el medio ambiente, México, UNAM, 2007, p. 10 (translated by the autor).
} 
of the assembly recognized the importance of nature preservation and included it in Article 27 of the Constitution.

For many years, environmental legislation in Mexico was considered as part of health regulation. Afterwards, it acquired some independence, when the ideas of ground and water preservation came about. Eventually, international trends and the development of public administration brought about concepts such as: sustainable development, environmental justice, collective and diffuse rights. Nowadays, environmental issues are fragmented by blocks of subjects. This and its divorce from social and economic issues have not allowed for a holistic perspective of the environment. Such a vision could transcend legalist views and set a trend of comprehensive and sustainable national development—a goal established by the constitution in numeral 25.

It now seems that what was accorded in the 66th ordinary session has been forgotten by Mexican society. One must "go back to history" in order to build a solid platform in which growth can be grounded on. Production, wasteful consumption, increasing environmental degradation, and a fragmented conception of the environment in Mexican legislation have all caused the ecosystems' resilience to collapse.

\section{The Importance of Landscape Heritage in Mexican Legislation}

Landscape heritage protects the right to a healthy environment. It is part of contemporary environmental sustainability, and it stands for protecting the ability of future generations to tend to their needs. This means that natural resources, ecosystems, and biodiversity should be preserved for future generations. The damages these have received have already affected the country's social development, by worsening the marginalization inherent to social exclusion and poverty ${ }^{8}$.

To speak of landscape is to recognize that culture, ecology, the environment, and society all favor a country's economic development. These are certainly elements that have effects on quality of life and welfare. An adequate conception of landscape heritage can enhance environmental rationality, understood as "the linking of culture and nature, based on an ethic of otherness, a dialogue among two different forms of knowledge and politics of difference" ${ }^{\text {"9 }}$. Society must internalize environmental matters, and relate natural processes to more efficient forms of society. An apt conception of nature preservation does not divorce ecology from society and culture; on the contrary, it integrates them.

Nowadays, the fragmented approach on the environment has blocked more comprehensive and inter-connected strategies. These would lead to a true quantification of environmental damage and would increase awareness. Mexico's environmental reality shows that speaking of protection is no more than a utopia. That which the law supposedly protects is, in some areas, gone, due to man's relentless production.

Landscape planning means restoring natural areas and aiming at sustainable development. This strategy can transform something as big as a metropole into "region-cities", and something as small as a backward rural community into "polycentric micro-regions". Mexico's environmental policy has focused on protected natural areas. It points them out as basic instruments for diminishing environmental impacts. However, region-cities and polycentric micro-regions are broader concepts that can strengthen a society's abilities to protect its environment. As societies move further away from nature, environmental damages have gone beyond borders, societies, and cultures.

\footnotetext{
${ }^{8}$ Pedro Gutiérrez Yurritia and Izarelly Rosillo Pantoja, 2010, "Fundamento jurídico-administrativo para la metamorfosis de una zona metropolitana en una ciudad región”, International Congress of Environmental and Territorial Studies, Guayana (publication pending).

9 Enrique Leff, Racionalidad ambiental. La reapropiación social de la naturaleza, México, Siglo XXI, 2004, p. 14.
} 
The amount of energy each city and micro-region intakes must be the same as the one it produces; its human and landscape energy must be self-generated. It is of utmost importance that the balance of energy between nature and city is maintained. Landscape conservation allows us to preserve Mexico's resilient ecosystems, even those inhabited by underprivileged communities- these are the most fragile ecosystems, and most vulnerable to environmental degradation ${ }^{10}$.

Landscape heritage preservation is an essential element, to be considered by Mexican legislation and comprehensive waste management. It is a crucial strategy for our heritage to be protected.

\section{The European Landscape Convention}

There cannot be social development without country-level and international cooperation. The European Landscape Convention (ELC) is a good example of the mechanisms that can be used for strengthening conservation strategies.

The ELC was signed by the member states of the Council of Europe on October 20, 2000. It is a legal instrument that recognizes the importance of landscape, cultures, and natural heritage, identifying them as part of the European identity. The ELC's goal is to promote the conservation, planning, and management of landscape $^{11}$. It refers to several documents of international law, stating that "The quality and diversity of landscapes are a common resource,” as they can benefit or damage human beings. The international documents addressing this issue also refer to the following subjects:

(1) Cross-border cooperation;

(2) Natural and cultural world heritage;

(3) Biological diversity;

(4) Landscape architecture;

(5) Citizen participation;

(6) Environmental justice.

Looking at these subjects together can foster a holistic conception of landscape heritage. It also allows us to integrate world heritage (referring to culture) and natural heritage (referring to the environment). This conception would consider landscape as a whole, erasing physical and imaginary borderlines. The goal is to strengthen environmental governance by means of cross-border cooperation (see Table 1).

Table 1

International Legal Framework Recognizing the Importance of Landscape Preservation

International legal framework recognizing the importance of landscape preservation

Convention on the Conservation of European Wildlife and Natural Habitats (Bern, 1979)

Convention for the Protection of the Architectural Heritage of Europe (Granada, 1985)

European Convention on the Protection of the Archeological Heritage (Valetta, 1992)

European Outline Convention on Transfrontier Co-Operation Between Territorial Communities or Authorities (Madrid, 1980)

European Charter for Local Self-Government (Strasbourg, 1985)

Convention on Biological Diversity (Rio de Janeiro, 1992)

Convention Concerning the Protection of the World Cultural and Natural Heritage (Paris, 1972)

Convention on Access to Information, Public Participation in Decision-Making and Access to Justice in Environmental Matters (Aarhus, 1998)

${ }^{10}$ P. Gutiérrez Yurrita, “Ecocentrismo vs. egocentrismo: socioecología y desarrollo humano”, Derecho Ambiental y Ecología, 3 (2007), pp. 44-55.

${ }^{11}$ Council of Europe, European Landscape Convention, http://www.cidce.org/pdf/Convenio\%20Paisaje.pdf. 
The ELC considers the following concepts:
(1) Landscape;
(2) Landscape policy;
(3) Landscape quality as goal;
(4) Landscape protection;
(5) Landscape planning;
(6) Landscape management.

Landscape is defined as, "Any part of the territory perceived as such by the population, whose constitution is the result of natural action and/or human interaction". This means that certain landscapes altered or created by men can also be protected as world heritage. Landscape conservation actions must be "aimed at preserving the most significant or characteristic aspects of a given landscape, determined as such due to their heritage value” (see Table 2).

Table 2

Obligations Undertaken by the Member States of the ELC

Obligations undertaken by the member states of the ELC

General requirements

Granting legal status to landscapes as an essential element of human environment, an expression of their diverse cultural and natural heritage, and a basis for their identity.

Defining and applying policies aimed at protecting, managing, and planning landscape, by adopting specific measures as outlined in Article 6.

Establishing procedures for the participation of the public, local and regional authorities, and other parties interested in the development and implementation of landscape policies.

Integrating landscape into land-use and urban policy, as well as cultural, environmental, agricultural, social, and economic policy, in addition to all policies that may directly or indirectly affect landscape.

Specific requirements

A. Awareness

Fostering awareness of the value and role of landscape among civil society, private organizations, and public authorities.

B. Training and education

Promoting:

The training of experts for the assessment and intervention of landscape.

Multidisciplinary programs for the protection, management, and planning of landscape, with easy access to private- and public-sector professionals and other interested organizations.

School and university courses that address the values related to landscape preservation.

C. Identification and classification

1. With an active participation of interested parties, according to Article 5.c, and in the spirit of deepening knowledge of landscape, parties commit to:

Identifying their own landscapes countrywide.

Analyzing each landscape's characteristics, strengths, and weaknesses.

Monitor changes in landscape.

Classifying landscapes according to their characteristics and the people's interest.

2. The processes of identification and classification will be guided by inter-party exchanges of expertise and methodology, according to Article 8.

D. Landscape quality standards

Parties commit to defining standards for landscape quality, with public consultations, according to Article 5.c.

E. Implementation

Parties commit to establishing instruments of intervention aimed at protecting, managing, and planning landscape.

The ELC's tools for protecting landscape are the following (see Figure 3): 


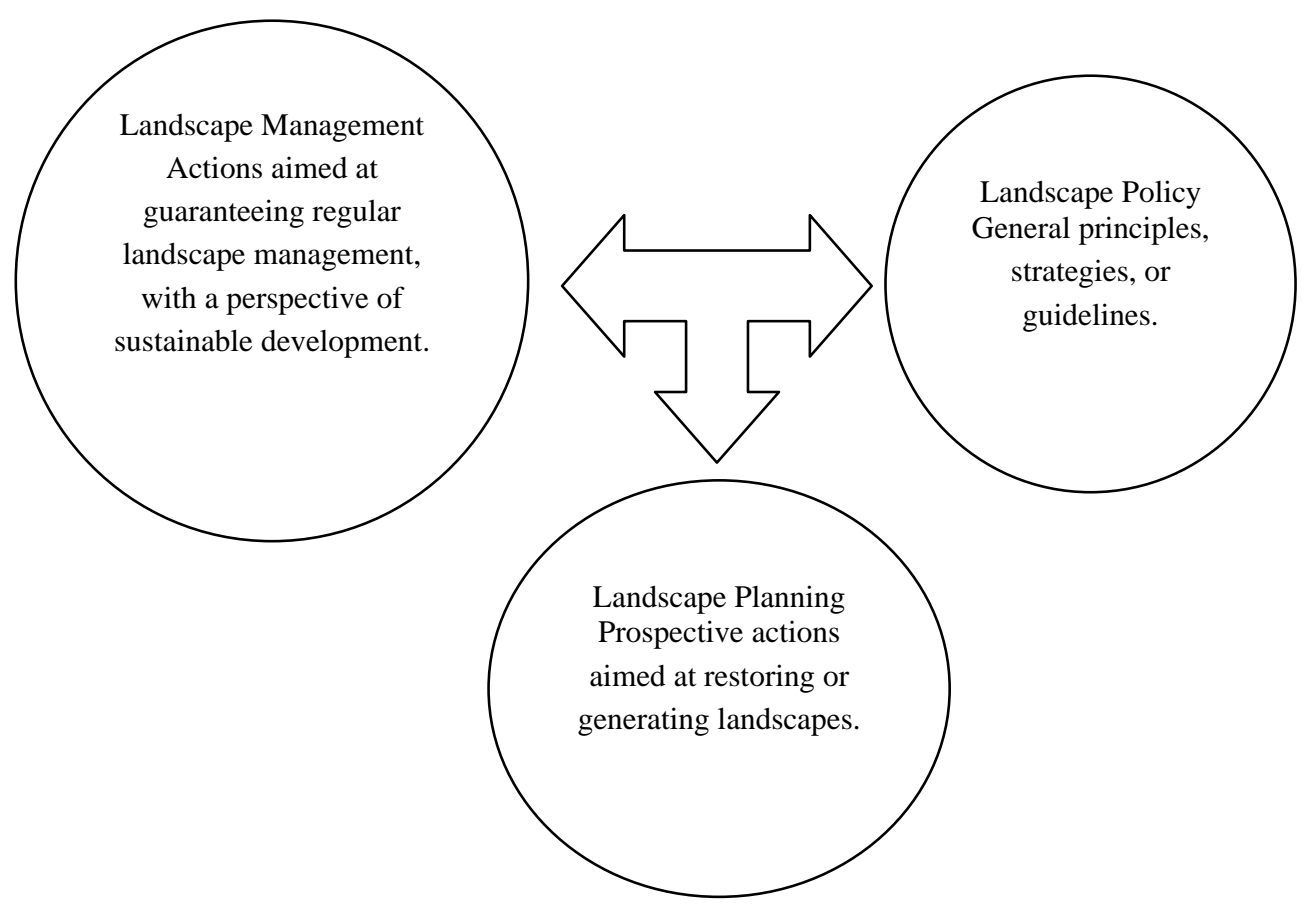

Figure 3. Legal instruments for protecting and preserving landscape.

\section{The Importance of Landscape Preservation for Comprehensive Waste Management}

Waste management is a borderless issue; it does not respect territorial or class divides. Environmental damage has already affected several city halls, state governments, and countries all over the world. As pollution is spread in rivers, oceans, the atmosphere, and the ground, health, quality of life, and social development are affected. One of the main impediments is the lack of transparency with which comprehensive waste management is conducted. This does not only affect health and the environment, but causes excessive costs and mismanagement of resources.

Many times, waste management resources are not appointed for this sole purpose, but depend on other budget areas. This makes it hard for experts to calculate the specific amount used for waste management, and often allows governments to conduct opaque transactions. Furthermore, workers of urban waste recollection conduct some practices that are detrimental to an adequate management of resources—such as expecting tips, separating, and recycling the waste themselves, and misusing the infrastructure. This can cause a disequilibrium of the public treasury and can lead to a neglect of environmental administration jurisdiction. Another problem is underprivileged people who work in landfills informally collecting recyclable materials, often exploited by mobs $^{12}$.

Producing and consuming goods is beneficial to society; it satisfies basic needs and boosts the economy. However, if the waste this activity produces is not managed adequately, environmental and health problems can arise. These problems are caused by an increased production of waste and weak management strategies and capabilities. It is complicated to make people reconsider their consumption habits and to implement shared responsibility and 3R systems (reduce, reuse, recycle).

12 Cortinas de Nava, Cristina, "Empoderamiento ciudadano y la gestión de los recursos”, Ecologismo, Ambientalismo, Sustentabilidad, http://www.cristinacortinas.net/index.php?option=com_content\&task=view\&id=42\&Itemid=27. 
In Mexico, daily waste generation is of 94,800 tons, amounting to 34.6 million tons a year. Waste can be divided as follows:

(1) Fifty-three percent (53\%) organic waste;

(2) Twenty-eight percent (28\%) potentially recyclable waste;

(3) Nineteen percent (19\%) not useful waste ${ }^{13}$.

Some diagnoses estimate that $87 \%$ of waste is collected, but only $64 \%$ is taken to sanitary landfills and controlled sites. The rest is taken to open garbage pits. Historically, waste management in Mexico has been focused on avoiding water pollution, as most waste used to be thrown into rivers. More recently, waste has been disposed of by burning it in open pits. Today, special legislation exists for handling waste, and it classifies waste into categories to enhance its management.

The real challenges ahead are growth of poverty, emigration, decreased oil sales and production, and world economic crisis. In this context, it is difficult for governments, private companies, and social organizations to focus on waste management. Efforts should start by identifying which places lack public or private waste collection services, recovering useful waste and reintroducing it into production chains, soil improvement processes, or energy production. Society should play a role in this. Civil organizations have evolved in recent years, but this has not been as true for waste management. Why is society unconnected from environmental damage, even it has proven to be detrimental to health?

What is happening? Are the media not providing enough information on the matter? Are authorities minimizing the problem? Is society aware but does not care? Have we lost environmental culture and fail to see the link between our daily lives and the environment? Where is an environmental responsibility that adequately reflects our history? Unfortunately, answers cannot be found under the segmented conception our laws have of the environment. Mexico's development ignores its cultural, environmental, and ecological bases. This is an aimless development, one that depends on wasteful consumption.

The common individual does not have a sense of belonging toward nature, but a sense of property. Discourse says, "This is why I pay taxes, this is not my problem", leading to a state of isolation, cultural disintegration, and diminished environmental rationality. As a result, people and their contexts are left weak and are easily manipulated.

Why is it important for comprehensive waste management to comprise landscape heritage? Because the concept of landscape entails a holistic vision of the environment that Mexico lacks. Applied to comprehensive waste management, said approach could lead us to an adequate conception of shared, differentiated responsibility toward the environment.

On the one hand, landscape heritage preservation takes into account sustainability, culture, and cross-border cooperation. It is a tool to integrate society and its landscape. On the other hand, environmental policy for waste management is based upon the principles of reduction, valorization, and shared responsibility. Its legal framework, the General Law for the Prevention and Comprehensive Management of Waste, has as a goal the fostering of sustainable development by means of waste management, the valorization and comprehensive management of hazardous waste, urban solid waste, and special-management waste. To achieve this, a program must be solid financially, and incorporate environmental education, social communication, responsible social

\footnotetext{
13 SEMARNAT, National Program for the Prevention and Management of Waste, p. 10, http://www.semarnat.gob.mx/ informacionambiental/publicaciones/Publicaciones/SEMARNAT\%20Resumen\%20Ejecutivo\%2009.pdf.
} 
participation, and an orderly legal framework.

The principles of landscape heritage preservation should apply to comprehensive waste management. The latter should incorporate cross-border cooperation, as waste management is also a borderless problem. Pollution can affect one or several municipalities, states, or countries at the same time. Cross-border cooperation could strengthen government strategies, by means of: inter-municipal associations, trans-municipal issues, decentralized organisms with state and municipal participation. This could work as a national strategy to crack ideological frontiers and develop comprehensive strategies (see Table 3).

Table 3

Framework for Landscape Heritage Preservation as Related to Comprehensive Waste Management

\begin{tabular}{|l|l|}
\hline Bases for the legal framework of landscape heritage preservation & $\begin{array}{l}\text { Bases for the legal framework of comprehensive waste } \\
\text { management }\end{array}$ \\
\hline Landscape & Waste \\
Natural heritage & Natural heritage \\
Cultural heritage & Biological diversity \\
Biological diversity & Citizen participation \\
Citizen participation & Cross-border government cooperation (inter-municipality and \\
Cross-border government cooperation & municipal associations) \\
Environmental justice & Environmental justice \\
\hline
\end{tabular}

Another way in which waste management could learn something from landscape heritage preservation is citizen participation. Landscape heritage preservation highlights society's relation to the environment, as it considers landscape to be an issue for everyone, not just for a few concerned parties. Waste management should work in the same way. Citizen participation should include those who are not familiar with waste management as a subject of study. It should urge everyone to strengthen their social and cultural links to the environment. Two main aspects should be reinforced: "good practices" (reintroducing culture into society) and historic practices of landscape preservation (see Table 3).

\section{Conclusions}

The holistic concept of landscape heritage preservation should be brought into comprehensive waste management. Programs dealing with waste management should question what was the previous management of waste in the site the program is being developed or the ones nearby. These programs should also photograph landscapes before and after environmental impacts, document possible health hazards, and recommend actions towards reducing our environmental footprint. We should all adopt practices of local trade, as citizens of first-world countries have been doing.

An improved comprehensive waste management could include the following strategies:

(1) Recognizing that landscape heritage preservation benefits society, especially underprivileged communities or indigenous groups;

(2) Introducing incentives for those who favor landscape heritage preservation under criteria of sustainability;

(3) Increasing awareness of social and private sectors as towards landscape heritage preservation, in processes of production and consumption.

Landscape preservation by means of comprehensive waste management is the key to individual and social wellbeing. Even if our legislation has not recognized or adequately guarded such a contemporary concept, its importance is well-known and could soon make it part of waste management plans and programs. This would 
make the programs stronger and eventually induce legislators to reform the law.

Continuing our day-to-day lives stops us from seeing the damage we do by distancing ourselves from our wild, rural, or even rustic urban landscape. Landscape heritage preservation could leave a historic legacy and allow future generations to grow with the same opportunities as present ones. Furthermore, an adequate landscape preservation could enhance sustainable economic growth—a goal stated in the Mexican constitution.

\section{References}

Congress of Mexico. (2003). General law for the prevention and management of waste. Retrieved from http://www.diputados.gob.mx/LeyesBiblio/pdf/263.pdf

Constitution of the United States of Mexico. (1917). Retrieved from http://www.diputados.gob.mx/LeyesBiblio/pdf/1.pdf

Cortinas de Nava, C. (2007). Citizen empowerment and comprehensive waste management. Ecologismo, Ambientalismo, Sustentabilidad (Ecology, Environmentalism, Sustainability). Retrieved from http://www.cristinacortinas.net/index.php? option=com_content\&task=view\&id=42\&Itemid=27

Council of Europe. (2000). European Landscape Convention. Florence.

Gutiérrez Yurrita, P. (2007). Ecocentrismo vs. egocentrismo: socioecología y desarrollo humano (Eco-centrism vs. egocentrism: Socio-Ecology and human development). Derecho Ambiental y Ecología (Environmental Law and Ecology), 3, 44-55.

Gutiérrez Yurritia, P., \& Rosillo Pantoja, I. (2009). Una secretaría de Estado con futuro: la Secretaría de Conservación del Patrimonio Paisajístico para la Sustentabilidad (A state ministry with future: The ministry for landscape heritage preservation and sustainability). Revista Derecho Ambiental y Ecología (Environmental Law and Ecology), 38-39(5), 55-78.

Gutiérrez Yurritia, P., \& Rosillo Pantoja, I. (2010). Legal and administrative foundations for the metamorphosis of a metropolitan zone into a region-city. Proceedings from the 5th International Congress of Environmental and Territorial Studies. Guayana.

INEGI (The National Institute for Statistics and Geography). (2004). Comunicado especial (Special communiqué). Retrieved from http://www.inegi.org.mx/inegi/contenidos/espanol/prensa/Boletines/Boletin/Comunicados/Especiales/2004/Junio/comunica3. doc

INEGI (The National Institute for Statistics and Geography). (2010). System of national accounts: Economic and ecological accounts of Mexico, 2006-2010, Mexico, INEGI, 2012. Retrieved from http://www.inegi. org.mx/prod_serv/contenidos/espanol/bvinegi/productos/derivada/economicas/medio\%20ambiente/2006-2010/SCEEM0610 PS.pdf

Leff, E. (2004). Racionalidad ambiental: La reapropiación social de la naturaleza (Environmental rationality: The social appropriation of nature). México: Siglo XXI.

Rabasa, E. (2007). La Constitución y el medio ambiente (The constitution and the environment). México: UNAM.

Rosillo Pantoja, I. (2015). Ética y justicia ambiental en el Estado constitucional mexicano (Ethics and environmental justice in the Mexican Constitutional State). In J. R. J. Gómez (Ed.), Ética y justicia. Reflexiones y planteamientos intemporales (Ethics and justice. Atemporary reflections and proposals). México: Porrúa.

SEMARNAT (Ministry of the Environment and Natural Resources). (2009a). National program for the prevention and management of waste. Retrieved from http://www.semarnat.gob.mx/informacionambiental/publicaciones/Publicaciones/ SEMARNAT\%20Resumen\%20Ejecutivo\%2009.pdf

SEMARNAT (Ministry of the Environment and Natural Resources). (2009b). Programa estratégico sobre el capital natural (Strategic program on natural capital). Retrieved from http://elearning.semarnat.gob.mx/cte/MATERIALESAPOYO/ DERECHO\%20AMBIENTAL/Contenidos/Documentos\%20oficiales/Programa\%20Estrat\%C3\%A9gico\%20sobre\%20el\%2 0Capital\%20Natural.doc

Suprema Corte de Justicia de la Nación (National Supreme Court of Justice). (2010). Jurisprudencia y tesis aisladas (Jurisprudence and related theses). Mexico: SCJN. 